\title{
Innovations
}

\section{The various faces of genomics in Islamic bioethics}

\author{
Medical Humanities in the Middle East Conference \\ November 17-18, 2018 \\ Doha, Qatar
}

\section{Authors}

Mohammed Ghaly ${ }^{*}$

\section{Introduction}

The Islamic bioethical discussions on genomics have been predominantly interdisciplinary, involving both Muslim religious scholars and biomedical scientists. These discussions started in the 1990s, as part of their ethical reflections on the then new Human Genome Project (HGP). Throughout the span of more than three decades, genomics had no one single face and various perspectives were introduced in the Islamic bioethical discourse. We give here an analytical review of the key discussions and various perspectives on genomics in the Islamic tradition, and examine how the advocates of each perspective argued that the face they defended was the true face of genomics.

\section{Islamic Bioethics \& Genomics}

By the beginning of the 1980s, Islamic bioethical deliberations assumed a strong interdisciplinary character through a systematic collaboration between Muslim religious scholars and biomedical scientists. Within this interdisciplinary framework, biomedical scientists took up the role of explaining the scientific and technical aspects of genomics in a jargon-free language. This explanation helps the religious scholars develop the necessary informed perception before embarking upon their role in the so-called process of ijtihad (independent reasoning), in which they examine the sources of Islamic moral normativity, especially Quran and Sunna. This interdisciplinary approach, known in Islamic studies as collective ijtihad, was adopted by three main institutions, namely the Islamic Organization for Medical Sciences (IOMS) based in Kuwait, the Islamic Figh Academy (IFA) in Mecca, and the International Islamic Fiqh Academy (IIFA) in Jeddah, Saudi Arabia. Available literature shows that Islamic bioethical deliberations on genomics witnessed their peak during the period 1993-2013.' During this three-decade period, two main faces of genomics predominantly featured, each of which is briefly outlined below.
'Hamad Bin Khalifa University (HBKU), Doha, Qatar

*Email: mghaly@hbku.edu.qa

\section{Cite this article as:}

Ghaly M. The various faces of genomics in Islamic bioethics. In: Weber AS, Verjee MA, editors. Proceedings of the 1st International Conference on Medical Humanities in the Middle East [Internet]; 2018 Nov 17-18: Doha, Qatar: Innovations in Global Health Professions Education; 2019 March. p. 8-10. (Innovations in Global Health Professions Education; vol. 2019, spec. no.: 1). https://dx.doi.org/10.20421/ighpe2019.01.01

This is an open access article distributed under the terms of the Creative Commons Attribution license CC BY 4.0, which permits unrestricted use, distribution and reproduction in any medium, provided the original work is properly cited. 


\section{The Suspicious Face}

Those who stressed the "suspicious" face of genomics premised their position on a broader and deeper mistrust in the Western scientific enterprise. Western countries can produce good science, they argued, but it is always divorced from religious values because of the dominant secular worldview. "Modern scientists have no religion to abide by except their own scientific imagination", one of the advocates of this position said. This alienation of the religious values means that the likelihood of misusing the power generated by genomics cannot be exaggerated. As a concrete example, they referred to the research on atomic energy which ended up developing and using the atomic bomb, which took the lives of so many innocents. Additionally, they referred to other associated risks including genetic discrimination, undermining people's privacy and the possibility of creating abnormal genes which can eventually harm people's health. By incorporating all these risks, the total benefit-risk assessment was not in favour of genomics. Hence, the proponents of this position concluded that both Muslim individual scientists and governments should better refrain from engaging in this new field, at least until these suspicions are cleared or that the risks can be efficiently controlled. ${ }^{2}$

\section{The Promising Face}

The advocates of the "promising" face of genomics criticized their opponents for being excessively suspicious. They did not see genomics as a "Western" project but rather as part of man's long journey to improve knowledge about our own human nature and the universe. The virtuous character of the searching-for-knowledge journey has been recurrently stressed in the Quran (e.g. "Say, 'Travel throughout the earth and see how He has originated the creation'"). ${ }^{3}$ Concerning the interplay of religion and science, they argued that the other group's judgement cannot be generalized, especially when it comes to genomics. They referred to Francis Collins, the HGP director, whose religious convictions even intensified during his work in this field. Even if science was completely divorced from religion, they argued, this should not mean that practicing science will inevitably entail unethical violations. Through developing and implementing strict regulations, practising science in Western academies proved to be compatible with (Islamic) ethics, even much better than in some Muslim countries. Concerning the benefit-risk assessment, the promising character of genomics and its potential to improve man's health were framed as an integral part of safeguarding life, which is one of the higher objectives of Sharia. The possible harms of genomics cannot overweigh the value of this benefit and they can always be minimized through a robust review system, they concluded. ${ }^{2}$

\section{Further Developments}

After three decades of deliberations on genomics, the promising face of genomics proved to be the true one for the overwhelming majority of Muslim scholars. In November 2013, the authoritative IIFA issued a resolution stating that genomics research is part of the religiously recommended search for the marvelousness of God's creation and thus calling Muslim countries to join the ongoing genomic revolution. ${ }^{2}$ In December 2013, both Qatar and Saudi Arabic announced their national genome projects and later similar projects in other Gulf countries started gaining momentum.'

\section{Conflicts of interest: None.}

Funding sources: None.

\section{References}

1. Ghaly M, editor; Sadoun E, Alkuraya F, Fakhro $\mathrm{K}$, Zawati $\mathrm{M}$, Ismail $\mathrm{S}$, et al. Genomics in the Gulf region and Islamic ethics. Doha, Qatar: World Innovative Summit for Health (WISH); 2016 [cited 2018 May 28]. Available from: http://www.wish.org.qa/wp-content/ uploads/2018/01/Islamic-Ethics-ReportEnglishFINAL.pdf

2. Ghaly M. Islamic ethics and genomics: mapping the collective deliberations of Muslim religious scholars and biomedical scientists. In: Ghaly M, editor. Islamic ethics and the genome question. Leiden, Netherlands: Brill Open; 2019. p. 47-51.

3. Quran. 29:20 


\section{About the author}

Mohammed Ghaly is Professor of Islam and Biomedical Ethics in the Research Center for Islamic Legislation and Ethics (CILE), Hamad Bin Khalifa University in Doha, Qatar. Ghaly's main research interest is the interplay of Islamic Ethics and biomedical technologies. He is the editor-in-chief of the Journal of Islamic Ethics, published by Brill. 